\title{
CHD4 Gene Mutation
}

National Cancer Institute

\section{Source}

National Cancer Institute. CHD4 Gene Mutation. NCI Thesaurus. Code C150477.

A change in the nucleotide sequence of the CHD4 gene. 